\title{
ANALYSIS ON HIGH SCHOOL STUDENTS' MATHEMATICAL CREATIVE THINKING SKILLS ON THE TOPIC OF SETS
}

\author{
Sri Islami Kulsum ${ }^{1}$, Wahyu Hidayat ${ }^{1}$ Tommy Tanu Wijaya ${ }^{2}$, Jessica Kumala ${ }^{3}$ \\ ${ }^{1}$ IKIP Siliwangi, Cimahi, Indonesia \\ ${ }^{2,3}$ Guangxi Normal Univerity, Guilin, China \\ sriislamikulsum@gmail.com
}

\begin{abstract}
The purpose of this research is to find students' mathematical creative thinking skills on solving mathematical problems by using several indicators. This study was conducted in 1st Pasundan High school in Cimahi. The data analysis that would be use is the quantitative and qualitative descriptive analysis. The subject of this research are the 10th grade 2 nd science students with a total of 22 students. The result of this research that is obtained from the fluency and flexibility indicator is in the low category with a percentage score of $56.8 \%$, with an average of 2.27 . When using the originality and elaboration indicator, it was also in the low category with a percentage score of $20.4 \%$ and $38.6 \%$ and average score of 0.81 and 1.54 respectively.
\end{abstract}

Keywords: Mathematical creative thinking skills, Sets, Senior High School

Learning must always be part of human because with learning, humans would be able to find their way in life, know limits of all their actions and to shape a civilised and knowledgable person that will allow us to be a high quality human resource. It is necessary for everyone to learn through education (T. T. Wijaya, Dewi, Fauziah, \& Afrilianto, 2018). Written in the 31st article of the 1945 constitution stated that everyone has the right to get education (Sirait, 2016). The government of Indonesia put into action a program of 12 years of compulsory education as a way to show the importance of education and to form more high quality people in Indonesia.

There are various knowledge such as religion, language, science, social and mathematics that will be taught in different level of classes. Talking about education and mathematics like what was reviewed (Saepuloh, 2013) about the purpose of studying mathematics that was defined by KTSP from ministry of education. It stated that the purpose of studying mathematics is so that students are able to understand the concept of mathematics, using reasoning ability, solving problems, using ideas with the help of symbols, tables, diagrams or other medias to make situation clearer or problem. Also, to have an attitude to value the use of mathematics in life (Hidayat, 2017). Creative thinking skills are needed to be able to reach that goal.

Humans are a creative living creature. External stimulus is one of the best way to push humans to bring out their creativity. Creative thinking skills in mathematics learning is the ability that enables students to find various solutions or idea to solve problems not only mathematical problems but the creativity that is needed in work. Career Centre Maine Department of Labour USA stated that creative thinking skills is one of the skills that is needed in work (Mardhiyyah et al., 2014). It is because in work, not only do they need smart people but they also need intelligent people that are full of ideas and innovation to support the progress of related agencies. Suherman stated that from the 13 skills or mathematical competence, creative thinking is one of the cognitive skills that is needed and hoping to be achieved by students from learning mathematics (Suherman, 2008). Studying mathematics is not 
only about studying algorithm, statistics or geometry. But there is another purpose which is to practice and to work up students' way of thinking to be more logical, creative, rational and critical.

Seeing from the results that has been done by a few observers, the students' mathematical creative thinking skills are fairly low. In (Faelasofi, 2017) the research that was done in STKIP Muhammadiyah Pringsewu Lampung where their research subject was students who had basic statistics lesson in the year of 2016-2017. The average score of their fluency was 64.24 , flexibility was 45.83 , Elaboration was 66.67. With this result, the students' creative thinking skills on the topic of probability was still low as their new score can reach up to 59.26. Different from the results that (Ismara \& Suratman, 2016) collected which stated that the students' score for fluency are in the high category as their result can reach up to $66.18 \%$. While their flexibility score was in the low category as the result was $39.71 \%$ and their originality score was also in the the low category with the result of $20.59 \%$.

Knowing how important the skill is for the students, researches are moved to do similar research to find out the students' mathematical creative thinking skills of a high school in Cimahi. This is a step to improve the teaching and learning experience in class.

\section{METHOD}

The method that will be use in the research is descriptive. Azwar said that the purpose of a descriptive research is to systematically and accurately picture out the fact and characteristic of a population or a specific field (Zuyyina, Wijaya, \& Senjawati, 2018). Descriptive research point out what is there about the variable, symptoms or situation (Faelasofi, 2017). While according to Nawawi the descriptive method is a procedure to solve problems by drawing/painting the research subject/object according to the current fact or situation (Ismara \& Suratman, 2016). The purpose of this research is to analyse the mathematical creative thinking skills that will be base on the TKBKM result and interview according to the fluency, flexibility, originality and elaboration indicators from the problems that will be given to students on the topic of sets (L. Wijaya, Rochmad, \& Agoestanto, 2015).

This research will take place in 1st Pasundah High school in Cimahi. The subject of this research is 10 th grade 2 nd science class with a quantity of 22 students. The data collection technique will be giving a test where the questions that will be tested have passed the validity dan reliability test so that it will be feasible to be use for data collection.

The qualitative descriptive and qualitative descriptive will be the analysis method of this research. Quantitative descriptive will be the percentage of every question where it will be the indicator of mathematical creative thinking. While qualitative descriptive will clarify the mathematical creative thinking skills into high, average or low. The steps to this analysis will be shown below:

1). The test result will be adjusted according to the marking scheme of mathematical creative thinking skills. Every question will be based on each indicator which are fluency, flexibility, originality and elaboration. 
Analysis On High School Students' Mathematical Creative Thinking Skills On The Topic Of Sets, Sri Islami Kulsum,

2). Calculate the percentage of each aspect/ indicator. Assumptions are the creative thinking skills of each indicator as $\mathrm{K}$.

$\mathrm{K}=\frac{P}{Q} \times 100$

$\mathrm{P}=$ The total score that is obtained by students for each indicator

$\mathrm{Q}=$ The maximum total score for each indicator

Then will be categorised based on the conversion score by Nurkanca \& Sunarta given in the table below:

Tabel 1

Score Conversion

\begin{tabular}{|c|c|}
\hline Percentage & Category \\
\hline $90,00 \leq \mathrm{K}<100$ & Very high \\
\hline $80,00 \leq \mathrm{K}<90,00$ & High \\
\hline $65,00 \leq \mathrm{K}<80,00$ & Average \\
\hline $55,00 \leq \mathrm{K}<65,00$ & Low \\
\hline $\mathrm{K}<55,00$ & Very low \\
\hline
\end{tabular}

(Faelasofi, 2017)

3). After knowing the score percentage of each indicator, categorise each creative thinking skill for the indicator.

\section{RESULTS AND DISCUSSION}

\section{Result}

This research took place in one of the high school in Cimahi. The subject of this research was chosen randomly with a quantity of 22 students. The creative thinking skills test based on the indicator was giving the students 4 problems where in each questions represents one indicator. After going through the data analysis procedure, the result of the students' mathematical creative thinking skill for each indicator was obtained. The result is shown below.

\section{Tabel 2}

Results of Mathematical Creative Thinking Skill Test

\begin{tabular}{|c|c|c|c|l|}
\hline $\begin{array}{c}\text { Aspect of Creative } \\
\text { Thinking Skills }\end{array}$ & Total Score & Average & $\begin{array}{c}\text { Percentage } \\
(\boldsymbol{\%})\end{array}$ & Category \\
\hline Fluency & 50 & 2,27 & 56,8 & Low \\
\hline Flexibility & 50 & 2,27 & 56,8 & Low \\
\hline Originality & 18 & 0,81 & 20,4 & Very Low \\
\hline Elaboration & 34 & 1,54 & 38,6 & Very Low \\
\hline
\end{tabular}


From table 2 we can see that the students' creative thinking skills on fluency and flexibility indicators are in the low category with a percentage of 56.8\% and with an average score of 2.27. For the originality and elaboration indicator are in the very low category with a percentage of $20.4 \%$ and $38.6 \%$ and an average score of 0.81 and 1.54 respectively

\section{Disccusion}

The purpose of this research is to know the students' mathematical creative thinking skills by using a few indicators. This research was held in 1st Pasundan High school in Cimahi. The subject of this research is the 10th grade 2 nd science class with a quantity of 22 students that are tested using 4 questions. The intention to investigate the students' mathematical creative thinking skills is to know how the students are able to solve the problems with various alternative ways using their own ideas. Below are the detailed discussion on the result of this research.

\section{1). Fluency}

Being able to think fluently will enable students to create more ideas. This criteria is about the ability to give various examples about sets that is in their everyday life. But according to the data analysis, the creative thinking skills on fluency are in the low category with an average score of 2.27 and with a percentage of $56.8 \%$ from a maximum score of 4 and 0 as the minimum.

Some students are able to give answers that the teachers expected where in students are able to give some examples of sets that is in their everyday life. Some students write examples according to the instruction, while others not accordingly. Almost all of the students have difficulty to find examples on sets and some did not give any answers.

Seeing from the interview, we can see that students are still not very familiar with the topic of sets including it's definition. That is why the creative thinking skills on fluency is categorised low as students are still not able to give a few correct answers because students still do not understand the topic in the questions.

\section{2). Flexibility}

The ability to think flexibly in this case is the ability for students to find various solutions or approach to a problem. In this case, students are expected to be able to find the connection between one sets to another and describe what their connections are. But according to the data analysis, the creative thinking skills on flexibility is not the low category as the average score is 2.27 with a score percentage of $56.8 \%$ from maximum score of 4 and 0 as the minimum.

Seeing from the test paper, students only wrote one answer when asked to find the relationship between one set to another. Some students were able to find more than one relationship but were not able to describe them. This happens because most of the students do not understand what the instruction and as a result the information given in the question did not help them to solve the problem.

From the interview, we can see that the reason behind questions not answered is not understanding the instructions given in the question. So, the information given were not helpful and this effects the completion of answers. The creative thinking skills on flexibility is in the low category because students 
are unable to find various solutions or approach to a problem due to no being able to understand the instruction on the questions given.

\section{3). Originality}

Being able to think originally means that students are able to come up with new ideas that are not cliche and not common. In this criteria, we expect students to be able to fill in the information that is given in the problem and make questions out of the problem given. But according to the result of the data analysis, the creative thinking skills on originality is in the very low category with an average score of 0.81 and a score percentage of $20.4 \%$ from a maximum score of 4 and 0 as the minimum.

After seeing the result of the test, we can see that almost all of the students did not answer the question for this indicator. Students gave common informations on the problem and did not complete them. They also did not made questions to it. The cause of this is not being able to understand the instruction on the question which causes the information given in the questions did not help them to solve the problem.

From the interview, we can see that the obstacle of not finishing the problem is not being able to understand the instruction given so the information given was not helpful and students are not use to open questions. This effects the answers given by students. That is why the creative thinking skills on originality is in the very low category because students are unable to give out ideas that are not cliche and not common

\section{4). Elaboration}

Being able to think elaborately means that students are able to complete a situation or problem dan to give detail that includes table, graph, picture, model dan words. This means that being able to picture out the information in the problem into a Venn diagram dan give detail to it. However, according to the data analysis, the creative thinking skills on elaboration is in the very low category as the average score in 1.54 with a score percentage of $38.6 \%$ where 4 is the maximum score and 0 as the minimum.

From the test result, students are still make mistakes on how to put in the information given into a diagram and the detail they gave is incomplete. They put the data into the Venn diagram wrongly and only give detail with what in known. There are some who only picture out the information into the diagram with a wrong placement of information. The reason behind this is not understanding the sets concept which made students unable to finish the problem according to the instruction.

Seeing from the interview, we can see that students do not understand complex concept on sets as they only understand the basic. As a result, when they are given a concept question, they do not know which comes first. This effects the completeness of the answers given. The creative thinking skills on elaboration is in the low category because students are unable to complete a situation/problem and give details that includes tables, graphs, picture, model and words.

\section{CONCLUSION}

The research result on high school students that was tested in the 1st Pasundan high school in Cimahi 
with a total of 22 students of 10 th grade 2 nd science class as the subject tested. The creative thinking skill test has 4 questions where each question represents one of the indicator were given to the students. After going through data analysis, we got the result of students' mathematical creative thinking skills for each indicator. The students' creative thinking skills on fluency and flexibility were in the low category with a score percentage of $56.8 \%$ and an average score of 2.27 for both indicator. While for originality and elaboration, they are in the very low category with a score percentage of $20.4 \%$ and $38.6 \%$ with an average score of 0.81 and 1.54 respectively.

\section{REFERENCES}

Faelasofi, R. (2017). Identifikasi Kemampuan Berpikir Kreatif Matematika Pokok Bahasan Peluang. Jurnal Edumath, 3(2), 155-163.

Hendriana, H dkk. (2017). Hard Skills Dan Soft Skills Matematik Siswa. Bandung: PT. Refika Aditama

Hidayat, W. (2017). Adversity Quotient Dan Penalaran Kreatif Matematis Siswa Sma Dalam Pembelajaran Argument Driven Inquiry Pada Materi Turunan Fungsi. KALAMATIKA Jurnal Pendidikan Matematika, 2(1), 15. https://doi.org/10.22236/kalamatika.vol2no1.2017pp15-28

Ismara, L., \& Suratman, D. (2016). Kemampuan Berpikir Kreatif Matematis Siswa dalam Menyelesaikan Soal Open Ended di SMP. Jurnal, 1-8.

Mardhiyyah, A., Model, P., Treffinger, P., Meningkatkan, U., Berpikir, K., \& Smp, M. S. (2014). Amelia Mardhiyyah , 2014 Penerapan Model Pembelajaran Treffinger Untuk Meningkatkan Kemampuan Berpikir Kreatif Matematis Siswa Smp Universitas Pendidikan Indonesia | repository.upi.edu | perpustakaan.upi.edu. (2007).

Masalah, A. L. B. (2013). Asep Rahmat Saepuloh, 2013 Penerapan Model Pembelajaran Sinektik Untuk Meningkatkan Kemampuan Representasi Dan Komunikasi Matematis Siswa SMP Universitas Pendidikan Indonesia | repository.upi.edu. 1-10.

Sirait, E. D. (2016). Pengaruh minat belajar terhadap Prestasi Bekajar Siswa PAI. Formatif : Jurnal Ilmiah Pendidikan MIPA, 6(1), 35-43. https://doi.org/http://journal.lppmunindra.ac.id/ index.php/Formatif/article/viewFile/750/659

Suherman, E. (2008). Model belajar dan Pembelajaran Berorientasi Kompetensi Siswa. Educare, 5(2), 1-30. Retrieved from http://jurnal.fkip.unla.ac.id/index.php/educare/article/view/62

Wijaya, L., Rochmad, \& Agoestanto, A. (2015). Analisis Kemampuan Berpikir Kreatif Matematis Siswa SMP Kelas VII Ditinjau dari Tipe Kepribadian. Unnes Journal of Mathematics Education. Wijaya, T. T., Dewi, N. S. S., Fauziah, I. R., \& Afrilianto, M. (2018). Analisis Kemampuan Pemahaman Matematis Siswa Kelas IX Pada Materi Bangun Ruang. UNION: Jurnal Ilmiah Pendidikan Matematika, 6(1), 19-28. https://doi.org/10.30738/.v6i1.2076

Zuyyina, H., Wijaya, T. T., \& Senjawati, E. (2018). Kemampuan Koneksi Matematis Siswa Smp Pada Materi Lingkaran. Jurnal LP3M - Universitas Sarjanawiyata Tamansiswa Yogyakarta, 4(2), 7990. 